\title{
The Politics of Post-Socialist Colour in Nimród Antal's Kontroll (2003)
}

\section{Lucia Szemetova}

https://doi.org/10.15664/fcj.v0i17.2080

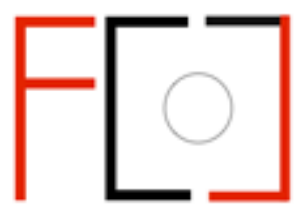

Frames Cinema Journal

ISSN 2053-8812

Issue 17 (Jun 2020)

(c) (i)

http://www.framescinemajournal.com 


\section{The Politics of Post-Socialist Colour in Nimród Antal's Kontroll (2003) Lucia Szemetova}

Kontroll (2003), Nimród Antal's directorial debut, is mostly known for its iconic location as it is set entirely in the Budapest metro system. In this gritty (fictional) environment, the film follows the fate of the cast-out Bulcsú (Sándor Csányi) who, escaping from his past, has resigned himself to a life underground. During the day he works as a ticket inspector, and at night he wanders the alienating labyrinth of Budapest's metro system. The film thematises systematised control and power structures inherited from the socialist past. It relocates them in a subterranean reality where individuals struggle to take command of their lives.

Although the director denies the political implications of his work, Kontroll is commonly assessed in the context of local identity politics. ${ }^{1}$ The film was released in 2003, a year before Hungary's "return to Europe", when the country's status would be determined in relation to the West. The EU accession re-opened the country's scepticism towards Western influences and highlighted disappointments brought on by the system change. However, it offered the country a chance to leave behind its socialist past. Whether consciously or not, while these concerns have been recognised in the film's narrative, they appear to have been overlooked in its aesthetics specifically, its colour palette.

This case study discusses the legacy of Cold War colour constructions and competition over colour cinema that determine the chromatic meanings in this film, lying at the intersection of history, politics, and identity. The provided analysis of the subversive use of colour in Kontroll hopes to illustrate a complex picture of self-representation in a crucial post-socialist moment.

The film's plot revolves around Bulcsú's miserable life underground; full of humiliating challenges and comical situations. Together with his team of misfits, he spends his days arguing with freeloaders, competing with rival colleagues, or chasing a young boy who plays tricks on them. Lacking any respect, these ticket inspectors are ridiculed, tricked, even beaten up daily, yet they take it with a sense of humour. In this oppressive reality, the only comfort for Bulcsú is a quirky passenger in a bear costume, Szofi (Eszter Balla), with whom he falls in love. Meanwhile, the metro system's image is facing a distressing threat as a rising number of passengers end up under the trains, for which the uncompromising bosses hold the ticket inspectors accountable. These apparent suicides are in fact murders, perpetrated by a mysterious hooded figure, who alarmingly resembles Bulcsú. The serial killer's motives and his existence remain ambiguous, leaving the audience to decide whether he is Bulcsú's alter ego or the embodiment of all the imagined evil roaming the dark underground. It is only after this unknown perpetrator's defeat that Bulcsú is finally able to ascend above ground, with the hope for a new life with Szofi.

Although Kontroll was marketed as a universal story between good and evil, it is the film's deliberately exaggerated representation of a post-socialist experience that has attracted critical attention. ${ }^{2}$ As György Kalmár argues, the film thematises the confusion in Hungary after the collapse of the totalitarian communist regime. ${ }^{3}$ Through addressing issues of inferiority complexes, and coming to terms with both the past and a possible new future, the film reflects on the postcolonial struggles of this former Eastern Bloc country. Kalmár refers to the double colonisation of Hungary - from the Soviet Union and then the capitalist West - where the latter strongly influenced the post-socialist countries' European integration. Deriving from a Eurocentric discourse, a term introduced by Ella Shohat and Robert Stam, the former Eastern Bloc countries were still considered as underdeveloped and separate from the leading West. ${ }^{4}$ Post-socialist films 
that thematise this East-West division and these issues of self-presentation for so-called periphery states such as Hungary, are thus often analysed in a post-colonial mode. ${ }^{5}$

A dominant practice in this region is the self-colonising imagination, which according to Alexander Kiossev "emerged as a spin-off in the process of Euro-colonial hegemony" - in this case referring to the West's epistemological domination during and after the Cold War. ${ }^{6}$ The selfcolonising or self-exoticising mode mimics the discursive power of an external observer. It relies on Western models to reproduce the common stereotypes with irony, resulting in a parodical selfimage. Thus, deploying this common representational method in Hungarian post-socialist cinema, Antal presents an Eastern space through a Western gaze by relying on stereotypes of backwardness and oppression, where characters strive to escape from their unliveable circumstances. ${ }^{7}$ Kontroll uses Western genres and narrative tropes, as it blends dark comedy together with the conventions of a crime thriller to overturn stereotypical associations with the East.

Recent scholarship on colour cinema stresses the necessity of chromatic aesthetics and technology not only as fundamental aspects of mise-en-scène but as important signifiers of a film's ideology and politics. ${ }^{8}$ The drab colour palette, which determines Kontroll's overall mysterious atmosphere, was previously associated with the Soviet colour film process, as well as with the whole region of the Eastern bloc as envisioned by the West. The stereotypical greyness of the Eastern bloc was a product of the Western imagination related to its material and political landscape. As Krisztina Fehérváry observes, the brutalist concrete-based architecture of the Eastern bloc led to a standard Western view that life behind the Iron Curtain was colourless and claustrophobic.' This concrete-like grey became shorthand for oppression, poverty, and depression, whereas colour signified the pleasures of capitalist consumption. ${ }^{10}$ In reality, however, the well-known housing estates were seldom grey and colour was abundant in the commercial sphere. ${ }^{11}$ Thus, often the grey-East association speaks of a Cold War construction or a nostalgic memory rather than a reflection of the presence of colour in everyday life under socialism. ${ }^{12}$ The colour grey's nuanced meanings, when used internally, can also signal that the colourful capitalist victory simply did not happen. Not surprisingly, post-socialism is often defined as a "grey zone", where grey does not stand for colourlessness but for ambiguity, uncertainty, and polarity, breaking away from previous unproductive East-West dichotomies. ${ }^{13}$ This in-between zone is neither in the oppressed past nor in the idealised future, and is filled with disappointment and confusion. Kontroll reflects on this moment of post-transition by establishing conventional colour binaries in order to challenge them, thereby showing the futility of such an approach.

These conventions were also established on the screen as post-war cinema's advances turned into a matter of competition between different countries and ideologies that politicised colour. ${ }^{14}$ In the 1940 s the American firm Technicolor dominated the film market, a colour film process connoting bright, high-key lighting and saturated colour aesthetics. Technicolor offered a high degree of colour standardisation and rapidly became a brand associated with quality and consistency suitable for mass production. Its primary European competitor with sufficient capital and diffusion was the Agfacolor process developed by the German company I.G. Farben based in Wolfen. ${ }^{15}$ Although Agfacolor was a cheaper and relatively simple process, due to exposure issues its aesthetic benchmark was muted and pastel as opposed to Technicolor's intensity. ${ }^{16}$ In 1945 the company in Wolfen was seized by Western forces taking hold of its technological foundations and consequently, its remains were relocated to the Soviet Occupation Zone. ${ }^{17}$ Thus, Agfacolor in Dudley Andrew's terms, was “typed as a 'socialist' method", despite the fact that it continued to thrive in the post-war world with patents taken by American, European, and Japanese interests, in 
addition to its Soviet successors. ${ }^{18}$ The latter developed the Sovcolor process, whose stereotypical desaturated look can be traced back to Agfacolor film stock's limitations in colour registration. Meanwhile, the Eastman Kodak Company, Agfa's rival since the 1930s, also released its chromogenic stock onto the market in this post-war period. ${ }^{19}$ The Eastmancolor process prevalent from the 1960s was known for the quality of its vibrant colour reproduction. This binary between the two processes became a trope influenced by political agendas, where as Andrew suggests, Eastmancolor was coded as a product of "American domination", while Sovcolor presented both an economic and aesthetic distaste for capitalist gaudiness. ${ }^{20}$ As Michelle Beutler points out, however, aesthetic standardisation was often "independent of the technological potentials" of these processes as issues of compatibility, quality, and institutional control played a more decisive role. ${ }^{21}$ According to official narratives, Eastern Bloc countries only used socialist stocks, yet they often imported American stocks as the economic needs for participation in global cinema markets meant privileging quality over political conflicts. ${ }^{22}$ The fact that Eastern bloc countries' films are still considered colourless further shows how official narratives did not mirror the reality of colour reproduction on the screen. ${ }^{23}$

In a self-colonising mode, Kontroll relies uniformly on a washed-out colour palette to challenge the stereotypical associations of representing an Eastern space through what David Crowley and Susan E. Reid call "the gray tinted glasses of Cold War". ${ }^{24}$ The film confronts the assumption that the drab era of socialism is in the past, and that a new, brightly coloured capitalist present is immanent by locating the perceived "Eastern look" in the disorienting capitalist present. By relying on colours discursively coded as socialist the film shows how Cold War politics of hierarchy continue to the present.

The clichéd Eastern drabness lends itself to the film being shot entirely on location in the Budapest metro system built in the 1970s, a landmark of socialist modernist architecture. Influenced by space travel and modern technology, the metro's steel grey topography resembles an allegorical dystopia of a non-organic labyrinth. As Kalmár observes, the metro is made of concrete, stone, metal, and glass materials that all evoke coldness and rigidity and constructs a distinctly Eastern space. ${ }^{25}$

Already the opening sequence's palette is symptomatic of the aesthetics of the film as a whole. In the first shot, as we follow a drunk woman (Eniko" Eszenyi) going down the escalators to the dark void, the monolithic style of the metro appears unwelcoming. The mise-en-scène fails to make the underground a familiar and pleasant place; there are no colourful advertisements, no music, no shops or cafés. It is a desolate place. The metro setting should be the epitome of movement, but instead, it stagnates as unpleasant, dirty, and most importantly, an unsafe territory. As we follow the woman stumbling on the platform, there are hints of red in the background as part of the set, such as red bins, seats, handrails, advertisement and lights, which provide a visual contrast to the darkness. In these compositions devoid of colour, the red comes across as overtly saturated and striking creating a sense of unease. Red's connotation of danger and death, being the colour of blood, is often used in slasher films to invoke fear and repulsion in the audience. ${ }^{26}$ The presence of red strengthens the thriller narrative in the film but also suggests the continuing legacy of the communist past. ${ }^{27}$ As the lonely passenger anxiously waits, the lights suddenly go off and she is pushed under the passing train leaving behind only her red shoe. Thus, this opening scene assists with establishing the stereotype that Eastern spaces are unliveable, and where individuals are under constant threat. Whereas the political system change was supposed to bring progress, the film presents the contemporary world as decaying and unnatural. The film's concrete-like 
reality with splashes of red, thus, problematises the idealistic representation of Western integration as an escape from oppressing socialism.

The use of cold, flat lighting positioned far away from the subjects and the narrow depth of field in the film further emphasises this menacing ambiance. After the mysterious crime committed by an unknown killer, we next see Bulcsú waking up on the platform as neon lights glare up above him. As we observe his daily routine he appears to get lost in this bleakness. The muted colour palette, with harsh artificial lights, thus mirrors the dullness and dreariness of Bulcsú's everyday life wasted underground as an inspector. He is unable to leave. Even during the night he cruises the grey brutalist underworld as a lonely figure on an inner quest. ${ }^{28}$ As opposed to the flat lighting during daytime, the use of low-key lighting at night transforms the familiar platforms and tracks into ominous, shadowy prisons. The contrasting lighting, a technique that is used often for science fiction, horror, or mystery thrillers, emphasises the two-identities of the metro and underlines the overall eerie mood of Kontroll. ${ }^{29}$ More importantly, it addresses what Márton Csillag calls "the schizophrenia of Hungarian society" in a post-transition period where new progress on the surface is artificial and the suppressed past in the subconscious is imprisoning. ${ }^{30}$ Both the director and cinematographer, Gyula Pados, insisted on shooting on $35 \mathrm{~mm}$ to achieve what they described as this specific "look and feel" of the film. ${ }^{31}$ The aesthetics of Kontroll derive from the contrast between an unpolished, nostalgic feel to the stock and artificial look of Tungsten lighting, which overall creates a modern, yet destructive atmosphere. This technique plays upon the trope of the East as run-down, painting a dystopian picture reinforced by the buzzing sound of the neon lights and fast-paced electronic music.

As opposed to this deliberately constructed "Eastern" nightmare the odd mix of characters brings a comedic aspect to the film. The ticket inspectors are the laughingstock of this new society, despised both for their profession and for their appearance. They symbolise the past legacy of authority, surveillance, and institutional control evoked by the colour red linked to them. The sign they wear on their forearm, a white " $\mathrm{M}$ " on a red surface brings to mind the symbol of the Arrow Cross Party as well as evoking the country's red past. However, it does not have any effect on the passengers. ${ }^{32}$ The inspectors themselves detest their job and disrespect their superiors as they jokingly call the head of the metro system, who has a red birthmark on his face, Gestapo. Despite their unhealthy appearance, they are the only living part of the decaying metro system. Even their skin colour becomes one with the grey and washed out green walls of the metro, making them appear sickly. ${ }^{33}$ Furthermore, their minimalist, desaturated costumes contributes to their perceived "Eastern" look as they appear smelly, poor, and "undemanding." 34 They wear faded jackets, shabby jumpers, and are overall dressed in shades of brown, black, and dark green. Thus, Bulcsú's team neither appears vital nor up-to-date, unable to break out from what Fehérváry calls "the grey confines of socialist era." ${ }^{35}$ As the ultimate underdogs in this changed society, their behaviour, appearance, and humiliating treatment by others makes them Eastern European caricatures. When Bulcsú realises that in order to escape from this prison he needs to confront the mysterious killer, revealed to him by Szofi in a dream sequence, he begins to physically suffer. Throughout the film his looks deteriorate extensively because of several beatings he receives. In the final chase scene with the killer however, Bulcsú manages to escape, allowing him to leave this cruel life behind. As Steve Jobbit argues, Bulcsú's way out could suggest "the integrative and redemptive fantasies" of a post-socialist country aiming for European membership. ${ }^{36}$ However, that the almost blinding lights are artificial rather than natural, indicates that Bulcsú is moving towards a non-existent utopia with Szofi, who happens to wear an angel-like costume. For the final shot, the camera stays 
underground, not following the characters as they move above ground because there is no escape from the colourless post-socialist situation. The idealised other place is non-existent. ${ }^{37}$

Although colour is often viewed as secondary to narrative or considered an excess, Kontrolls aesthetics demonstrate the significance that colour carries in post-socialist Hungarian cinema. ${ }^{38}$ By relying on a washed-out colour palette, often disrupted with saturated red, the film engages with the Cold War colour discourse. The film combines colours traditionally associated with the East to highlight how the prevalent devaluation of former communist countries by the West endures even after the fall of the Iron Curtain. Its use of grey challenges the persistence of the past in the new capitalist present, the problems of control and suppression of the individual remain, just now in other forms. The post-socialist space is suffocating both from the past and present, its exaggerated construction problematises East-West binaries on the screen. The film's seemingly utopian ending, thus finally destroys both the image of the drab East and colourful West and confronts such discursive categories. Kontroll points toward a need for a new trend where colour could become a primary tool for a self-representation devoid of stereotypes.

\footnotetext{
${ }^{1}$ Works that assess the film within the context of identity politics: Steve Jobbitt, "Subterranean Dreaming: Hungarian Fantasies of Integration and Redemption" Kinokultura (2008), http://www.kinokultura.com/specials/7/kontroll.shtml, Accessed May 2, 2020.; György Kalmár, "Inhabiting the Post-Communist (Kontroll. Nimród Antal, 2003)" in Formations of Masculinity in Post-Communist Hungarian Cinema: Labyrinthian Men, ed. György Kalmár (Cham: Springer International Publishing, 2017), 67-91, https://doi.org/10.1007/978-3-319-63664-1 4.; Kalmár, “Apostate Bodies: Nimród Antal's Kontroll and EasternEuropean Identity Politics," in Spaces, Bodies, Memories. Cultural Studies Approaches in the Study of Eastern European Cinema, ed. Andrea Virginás (Cambridge Scholars Publishing, 2017), 112-131.; Christine Grimes Topping, "The World Is out of Control: Nimrod Antal's Kontroll (2003) as a Socio-Political Critique of Powerless Individuals in a Postmodern World," Studies in European Cinema 7.3 (December 1, 2010): 235-45,

https://doi.org/10.1386/seci.7.3.235 1.; Owen Evans, "Going Underground: Margins, Dreams and Dark Spaces in Nimród Antal's Kontroll (2003)" The Urban Uncanny: A Collection of Interdisciplinary Studies, ed. Lucy Huskinson (London and New York: Routledge, 2016) 18-33.

2 The film opens with a disclaimer read out by the director of BKK (Budapest Public Transport Centre) who stresses that despite the familiar locations the film is entirely fictious.

${ }^{3}$ Kalmár, "Apostate Bodies," 112-131.

${ }^{4}$ László Strausz discusses the concept of Eurocentrism in relation to Hungarian cinema in: "Visszabeszélés és önegzotizálás. (A posztkolonialista elméletek kelet-európai alkalmazhatóságáról)" [Talking back and selfexoticisation. The use of post-colonial theory in Eastern context] Pannonbalmi Szemle XXII (2014): 104-119.; Although Shohat and Stam do not discuss the Eastern bloc, the book helps to understand and consequently challenge the West as a dominating construct. Ella Shohat and Robert Stam, Unthinking Eurocentrism (London, 1994). ${ }^{5}$ Periphery states are the former colonised, their attempts to define their own culture is a post-colonial gesture. Further details on how this applies to Hungarian cinema in: Strausz, "Visszabeszélés és önegzotizálás." [Talking back and self-exoticisation.] 104-119.

${ }^{6}$ Alexander Kiossev, "The Self-colonization Metaphor." Atlas of Transformation (2008) http://monumenttotransformation.org/atlas-of-transformation/html/s/self-colonization/the-self-colonizingmetaphor-alexander-kiossev.html. Accessed May 3, 2020.

${ }^{7}$ A detailed study on New Hungarian Cinema (a generation of directors starting to make films in the early 2000s) in a post-colonial framework: Gábor Gelencsér, "Back and Forth. De-Europeanization as self-colonization in Hungarian film after 1989," Studies in Eastern European Cinema 9.1 (2018): 63-75.; Anikó Imre (ed.), A Companion to Eastern European Cinemas (Malden, Oxford, Chichester, 2012).; Eva Mazierska et al., Postcolonial Approaches to Eastern European Cinema: Portraying Neighbours On-Screen (London: I.B. Tauris, 2015).

${ }^{8}$ Sarah Street and Joshua Yumibe, Chromatic modernity: color, cinema, and media of the 1920s (New York: Columbia University Press, 2019).; Richard Misek, Chromatic cinema: a bistory of screen color (Chichester, U.K.: Wiley-Blackwell, 2010); Sarah Street, "The Monopack Revolution, Global Cinema and Jigokumon/Gate of Hell (Kinugasa Teinosuke, 1953)" Open Screens 1, no. 1 (6 June 2018): 2. https://doi.org/10.16995/os.2.;

${ }^{9}$ Krisztina Fehérváry, Politics in Color and Concrete: Socialist Materialities and the Middle Class in Hungary (Indiana University Press, 2013).
} 
${ }^{10}$ Regina Lee Blaszczyk and Uwe Spiekermann, eds., Bright Modernity (Cham: Springer International Publishing, 2017), https://doi.org/10.1007/978-3-319-50745-3.

${ }^{11}$ Scholars have rejected the idea of greyness dominating everyday socialist reality. Further details in: Maroš Krivy',

"Greyness and colour desires: the chromatic politics of the panelak in late-socialist and post-socialist

Czechoslovakia," The Journal of Architecture 20.5 (2015): 765-802, https://doi.org/10.1080/13602365.2015.1088053.;

David Crowley and Susan E. Reid (ed), Pleasures in Socialism: Leisure and Luxury in the Eastern Bloc (Northwestern

University Press, 2010).

12 This debate is especially fruitful in the German context. For further details see: Sebastian Heiduschke, East German

Cinema: DEFA and Film History (New York: Palgrave MacMillan, 2013).; Wendy Westphal, "'Truer than the Real

Thing': 'Real' and 'Hyperreal' Representations of the Past in 'Das Leben Der Anderen”' German Studies Review 35.1

(2012): 97-111.

${ }^{13}$ Ida Harboe Knudsen and Martin Demant Frederiksen (eds), Ethnographies of Grey Zones in Eastern Europe: Relations,

Borders and Invisibilities (London; New York, NY: Anthem Press, 2015). David Batchelor also discusses grey as a

"colour of in between," more details in: Luminous and the Grey (London: Reaction Books, 2014).

${ }^{14}$ For a more detailed analysis of technology and colour discourse see: Dudley Andrew, "The Postwar Struggle for

Color," Cinema Journal 18.2 (1979): 41-52, https://doi.org/10.2307/1225441.; Barry Salt, Film style and technology:

history and analysis (London: Starword, 2009); Michelle Beutler, "Standardising Color Film. Technicolor No. IV and

Agfacolor during the 1940s," in Color Mania. The Material of Color in Photography and Film, ed. Barbara Flückiger, Eva

Hielscher, Nadine Wietlisbach (Lars Müller Publishers, 2019) 197-211.; Josephine Diecke, "Agfacolor in

(Intern)National Competition" in Color Mania, 211-223.

${ }_{15}$ Agfacolor was also a three-colour-subtractive process but using a traditional black-and-white camera unlike

Technicolor for which one had to hire a a whole team and a range of services, including a special camera and camera operator, the colour consultancy of the Colour Advisory Service and special laboratory processing. More details about the key differences between the two processes in: Beutler, "Standardising Color Film," 197-211.

16 Ibid, 199-200.

${ }^{17}$ Alice Lovejoy gives a detailed account of the dispersal of the Agfa patents in: "Celluloid geopolitics: film stock and the war economy, 1939-47," Screen 60.2 (Summer 2019): 224-241,

https://doi.org/10.1093/screen/hiz009.

18 Agfa derivates: Ferraniacolor, Ansco Color, Gevacolor, Sovcolor and Orwocolor. Further details in Diecke, "Agfacolor in (Intern)National Competition," 211-223; Andrew, "The Postwar Struggle for Color," 46.

${ }^{19}$ Diecke traces the history of Agfa and Kodak in: "Agfacolor in (Intern)National Competition," 211-3.; Heather

Heckman challenges the common misconception that Eastmancolor was responsible for destroying the Technicolor monopoly. The anti-trust suit in 1947, which launched the release of chromogenic stocks, was precisely because Kodak worked in collusion with Technicolor. Further details about the relationship between Technicolor and Eastmancolor in: "We've Got Bigger Problems: Preservation during Eastman Color's Innovation and Early Diffusion," Moving Image 15.1 (July 2015): 44-61.

${ }^{20}$ Andrew, "The Postwar Struggle for Color," 51.

${ }^{21}$ Beutler, "Standardising Color Film," 202. Andrew's assumptions about post-war Agfacolor associations and its contrast to Eastmancolor are complicated by the work of Beutler and Diecke who point out the diverse uses of the original patents and the similarities between the two processes.

22 Anna Batistová outlines how Czechoslovak film industry, though isolated in the Eastern Bloc, also followed the international adoption of widescreen in the 1950s for which it was forced to use Eastmancolor. Further details in: Anna Batistová, “Glorious Agfacolor, Breathtaking Totalvision, and Monophonic Sound. Colour and 'Scope' in Czechoslovakia, in Color and the moving image: history, theory, aesthetics, archive, 47-55.; Tereza Frodlová, "In the colours of Agfacolor. Introduction of colour to Czechoslovak cinema of the 1940s and 1950s," In Lucie Česálková, Czech Cinema Revisited (Prague: National Film Archive, 2017) 277-301. ISBN 978-80-7004-181-9.; Interview with János Kende (Hungarian cinematographer working from the 1960s): Ágnes Kovács, "Beszélgetés Kende Jánossal. Fények, világok.” [Interview with János Kende. Iights and Worlds], Filmvilág.hu http://www.filmvilag.hu/xista frame.php?cikk id=13999, Accessed May 2, 2020.

${ }^{23}$ Dina Iordanova discusses how the majority of East Central European films were dismissed by Western viewers for their "vision of metaphoric greyness." Whereas, as she argues, when looked closely the filmmakers used greyness consciously to argue for individuality devoid of politics. Further details in: Cinema of the Other Europe: The Industry and Artistry of East Central European Film (London: Wallflower Press, 2003) 93.

${ }^{24}$ Crowley and Reid, Pleasures in Socialism, 10.

${ }^{25}$ Kalmár, "Inhabiting the Post-Communist," 70.

${ }^{26}$ Mark Richard Adams, "Roses are Red, Violence is Too: Exploring Stylistic Excess in Valentine," in Style and Form in the Hollywood Slasher Film, ed. Wickham Clayton (Springer, 2015) 92-106, 96.

27 Since the twentieth century, red, besides acting as a primary signifier of (often contradictory) emotions such as love, passion, anger, or madness, has also become the colour of the Communist revolution. For further details see: Paul Coates, The Red and the White: The Cinema of People's Poland (London: Wallflower, 2005). This is not limited to Europe, but also included in Asia. More detail on the use of red in Chinese cinema and its relation to the communist 
regime in Chris Berry, "Every Colour Red? Colour in the Films of the Cultural Revolution Model Stage Works," Journal of Chinese Cinemas 6.3 (January 2012): 233-46, https://doi.org/10.1386/jcc.6.3.233 1.; Zhaoyu Zhu, "Weaponised Colour: A Brief History of the Dye-Transfer Process in China's Cultural Revolution" Colour and Film (2019), https://colourandfilm.com/2019/01/23/weaponised-colour-a-brief-history-of-the-dye-transfer-process-inchinas-cultural-revolution-by-zhaoyu-zhu/. Accessed May 27, 2020.

${ }^{28}$ Kalmár, "Inhabiting the Post-Communist," 90.

${ }^{29}$ Bill Goodykoontz and Christopher P. Jacobs, Film: From watching to seeing, Second Edition (San Diego, CA: Bridgepoint Education, Inc., 2014) 133-163.

${ }^{30}$ Márton Csillag, "Local Trains," Filmkultura.hu, https:// filmkultura.hu/regi/2004/articles/films/kontroll.en.html, Accessed May 27, 2020.

${ }^{31}$ Interview with the director: Walter Chaw, “The Thinking Man's Nimrod: FFC Interviews Nimrod Antal” Film Freak Central.net (2015), https://www.filmfreakcentral.net/ffc/2015/07/the-thinking-mans-nimrod-ffc-interviews-nimrodantal.html, Accessed April 15, 2020.

32 The Arrow Cross Party was a far-right party in power shortly during WWII in Hungary.

${ }^{33}$ Reproduction of flesh tones is crucial for all colour film processes to achieve reality effect. However, Kontroll goes deliberately against it to create a connection between the characters and the space. For further details on accurate skin tone in cinema see: Brian Winston, "A Whole Technology of Dyeing: A Note on Ideology and the Apparatus of the Chromatic Moving Image.” Daedalus 114.4 (1985): 105-23.

${ }^{34}$ For further discussion on how people from Eastern Germany were described by Western Germans in: Fehérváry, Politics in Color and Concrete, 181-2.

${ }^{35}$ Fehérváry, Politics in Color and Concrete, 221.

36 Jobbitt, "Subterranean Dreaming."

${ }^{37}$ Kalmár, "Apostate Bodies," 115.

${ }^{38}$ Brian Price, "General Introduction," in Color: The Film Reader, ed. Angela Dalle Vacche, Brian Price (Routledge, 2006) 6.

\section{Bibliography}

Adams, Mark Richard. "Roses are Red, Violence is Too: Exploring Stylistic Excess in Valentine." In Style and Form in the Hollywood Slasher Film. Ed. Wickham Clayton. Springer, 2015. 92106.

Andrew, Dudley. “The Postwar Struggle for Color.” Cinema Journal 18, no. 2 (1979): 41. https://doi.org/10.2307/1225441.

Batchelor, David. Luminous and the Grey. London: Reaction Books, 2014.

Batistová, Anna. "Glorious Agfacolor, Breathtaking Totalvision, and Monophonic Sound. Colour and 'Scope' in Czechoslovakia." In Color and the Moving Image: History, Theory, Aesthetics, Archive. Ed. Brown, Simon, Sarah Street, and Liz I. Watkins. New York, N.Y.: Routledge, 2013. 47-55.

Berry, Chris. "Every Colour Red? Colour in the Films of the Cultural Revolution Model Stage Works." Journal of Chinese Cinemas 6.3 (January 2012): 233-46. https://doi.org/10.1386/jcc.6.3.2331.

Beutler, Michelle. "Technicolor No. IV and Agfacolor During the 1940s. In Color Mania. The Material of Color in Photography and Film. Ed. Barbara Flückiger, Eva Hielscher, Nadine

Wietlisbach. Lars Müller Publishers. 197-211.

Blaszczyk, Regina Lee, and Uwe Spiekermann, eds. Bright Modernity. Cham: Springer International Publishing, 2017. https://doi.org/10.1007/978-3-319-50745-3.

Brown, Simon, Sarah Street, and Liz I. Watkins. Color and the Moving Image: History, Theory, Aesthetics, Archive. New York, N.Y.: Routledge, 2013.

Chaw, Walter. "The Thinking Man's Nimrod: FFC Interviews Nimrod Antal.” Film Freak

Central.net. https://www.filmfreakcentral.net/ffc/2015/07/the-thinking-mans-nimrodffc-interviews-nimrod-antal.html. Accessed April 15, 2020. 
Coates, Paul. The Red and the White: The Cinema of People's Poland. London: Wallflower, 2005.

Crowley, David, and Susan E. Reid, editors. Pleasures in Socialism: Leisure and Luxury in the Eastern Bloc. Northwestern University Press, 2010.

Csillag, Márton. "Local Trains." Filmkultura.bu. https://filmkultura.hu/regi/2004/articles/films/kontroll.en.html, Accessed May 27, 2020 .

Diecke, Josephine. "Agfacolor in (Intern)National Competition.” In Color Mania. The Material of Color in Photography and Film. Ed. Barbara Flückiger, Eva Hielscher, Nadine Wietlisbach. Lars Müller Publishers, 2019. 211-223.

Evans, Owen. "Going Underground: Margins, Dreams and Dark Spaces in Nimród Antal's Kontroll (2003)." The Urban Uncanny: A Collection of Interdisciplinary Studies. Ed. Lucy

Huskinson. London and New York: Routledge, 2016. 18-33.

Fehérváry, Krisztina. Politics in Color and Concrete: Socialist Materialities and the Middle Class in Hungary. Indiana University Press, 2013.

Frodlová, Tereza. "In the Colours of Agfacolor. Introduction of Colour to Czechoslovak Cinema of the 1940s and 1950s." In Lucie Cesálková. Czech Cinema Revisited (Prague: National Film Archive, 2017) 277-301. ISBN 978-80-7004-181-9.

Gelencsér, Gábor. "Back and Forth. De-Europeanization as Self-Colonization in Hungarian Film after 1989." Studies in Eastern European Cinema 9, no. 1 (January 2, 2018): 63-75. https://doi.org/10.1080/2040350X.2017.1404703.

Goodykoontz, Bill and Jacobs, Christopher P. Film: From Watching to Seeing, Second Edition. San Diego, CA: Bridgepoint Education, Inc., 2014.

Haines, Richard W. Technicolor Movies: The History of Dye Transfer Printing. Jefferson, NC: McFarland, 2010.

Heckman, Heather. 'We've Got Bigger Problems: Preservation During Eastman Color's Innovation and Early Diffusion." Moving Image 15.1 (July 2015): 44-61.

Heiduschke, Sebastian. East German Cinema: DEFA and Film History. New York: Palgrave MacMillan, 2013.

Imre, Anikó, (Ed). A Companion to Eastern European Cinemas. The Wiley-Blackwell Companions to National Cinemas. Chichester: Wiley-Blackwell, 2012.

Iordanova, Dina. Cinema of the Other Europe: The Industry and Artistry of East Central European Film. London: Wallflower Press, 2003.

Jobbitt, Steve. "Subterranean Dreaming: Hungarian Fantasies of Integration and Redemption" Kinokultura (2008). http://www.kinokultura.com/specials/7/kontroll.shtml. Accessed May 2, 2020.

Kalmár, György. “Apostate Bodies: Nimród Antal's Kontroll and Eastern-European Identity Politics.” In Spaces, Bodies, Memories. Cultural Studies Approaches in the Study of Eastern European Cinema. Cambridge Scholars, 2017.

"Inhabiting the Post-Communist (Kontroll. Nimród Antal, 2003)." In

Formations of Masculinity in Post-Communist Hungarian Cinema. Cham: Springer International Publishing, 2017. https://doi.org/10.1007/978-3-319-63664-1.

Knudsen, Ida Harboe and Frederiksen, Martin Demant (eds). Ethnographies of Grey Zones in Eastern Europe: Relations, Borders and Invisibilities. London; New York, NY:

Anthem Press, 2015. 
Kovács, Ágnes. "Beszélgetés Kende Jánossal. Fények, világok.” [Interview with János Kende. Lights and Worlds.]

Filmvilág.bu http://www.filmvilag.hu/xista frame.php?cikk id=13999. Accessed May 2, 2020.

Krivý, Maroš. "Greyness and Colour Desires: The Chromatic Politics of the Panelák in Late Socialist and Post-Socialist Czechoslovakia." The Journal of Architecture 20.5 (September 3, 2015): 765-802. https://doi.org/10.1080/13602365.2015.1088053.

Lovejoy, Alice. "Celluloid Geopolitics: Film Stock and the War Economy, 1939-47." Screen, Volume 60.2 (Summer 2019): 224-241, https://doi.org/10.1093/screen/hjz009.

Mayorov, Nikolai. 'Soviet Colours'. Studies in Russian and Soviet Cinema 6, no. 2 (September 2012): 241-55. https://doi.org/10.1386/srsc.6.2.241 1.

Mazierska Eva, Kristensen, Lars and Eva Näripea. Postcolonial Approaches to Eastern European Cinema: Portraying Neighbours On-Screen. London: I.B. Tauris, 2015.

Misek, Richard. “'Last of the Kodak': Andrei Tarkovsky's Struggle with Colour.” In Questions of Colour in Cinema: From Paintbrush to Pixel. New Studies in European Cinema. Ed.

Everett, Wendy E. Oxford, New York: Peter Lang, 2007. 161-179. . Chromatic cinema: A History of Screen Color. Chichester, U.K.: Wiley-Blackwell, 2010.

Price, Brian. "General Introduction." In Color: The Film Reader. Ed. Angela Dalle Vacche, Brian Price. Routledge, 2006.

Salt, Barry. Film Style and Technology: History and Analysis. London: Starword. 2009.

Shohat, Ella and Stam, Robert. Unthinking Eurocentrism. London, 1994.

Strausz, László. "Visszabeszélés és önegzotizálás. (A posztkolonialista elméletek kelet-európai alkalmazhatóságáról)." [Talking back and self-exoticisation. The use of post-colonial theory in Eastern context]. Pannonbalmi S zemle XXII (2014): 104-119.

Street, Sarah. 'The Monopack Revolution, Global Cinema and Jigokumon/Gate of Hell (Kinugasa Teinosuke, 1953)'. Open Screens 1, no. 1 (6 June 2018): 2. https://doi.org/10.16995/os.2.

Street, Sarah and Yumibe, Joshua. Chromatic Modernity: Color, Cinema, and Media of the 1920s. New York : Columbia University Press, 2019.

Grimes Topping, Christine. "The World Is out of Control: Nimrod Antal's Kontroll (2003) as a Socio-Political Critique of Powerless Individuals in a Postmodern World.” Studies in European Cinema 7, no. 3 (December 1, 2010): 235-45. https://doi.org/10.1386/seci.7.3.235 1.

Westphal, Wendy. “'Truer than the Real Thing': 'Real' and 'Hyperreal' Representations of the Past in 'Das Leben Der Anderen'.” German Studies Review 35.1 (2012): 97-111.

Winston, Brian. "A Whole Technology of Dyeing: A Note on Ideology and the Apparatus ofthe Chromatic Moving Image.” Daedalus 114.4 (1985): 105-23.

Zhu, Zhaoyu. "Weaponised Colour: A Brief History of the Dye-Transfer Process in China's Cultural Revolution." Colour and Film (2019). https://colourandfilm.com/2019/01/23/weaponised-colour-a-brief-history-of-the-dyetransfer-process-in-chinas-cultural-revolution-by-zhaoyu-zhu/. Accessed May 27, 2020.

\section{Filmography}

Kontroll. Directed by Antal Nimród. Budapest: Budapest Film. 2003. 


\section{About the Author}

Lucia Szemetova is currently finishing her taught postgraduate degree at the Department of Film Studies, University of St Andrews, UK. She completed her previous master's in Nationalism Studies at the Central European University, Hungary. In the upcoming academic year, she will be continuing at St Andrews as a Film Studies $\mathrm{PhD}$ with the project on the use of archive in Hungarian documentary films across three different socio-political contexts. Her research interests include the intersection of nationhood and cinema, post-socialist identity politics and visual media, and found footage reappropriation in documentary films. 